\title{
Immunization with Recombinant Surface Antigens p26 with Freund's Adjuvants against Babesia rodhaini Infection
}

\author{
Ikuo IGARASHI, Urara ASABA, Xuenan XUAN, Yoshitaka OMATA ${ }^{1)}$, Atsushi SAITO ${ }^{1)}$, Hideyuki NAGASAWA, \\ Kozo FUJISAKI, Naoyoshi SUZUKI, Yoichiro IWAKURA ${ }^{2)}$ and Takeshi MIKAMI \\ The Research Center for Protozoan Molecular Immunology and ${ }^{1)}$ Department of Veterinary Physiology, Obihiro University of Agriculture \\ and Veterinary Medicine, Obihiro, Hokkaido 080-8555, and ${ }^{2)}$ Institute of Medical Sciences, The University of Tokyo, Tokyo 108-0071, \\ Japan
}

(Received 20 May 1999/Accepted 2 March 2000)

ABSTRACT. The surface proteins of Babesia rodhaini have previously been shown to induce a high degree of protective immunity. In the present study, one of those proteins, B. rodhaini antigen p26 was expressed in Escherichia coli and in insect cells infected with a recombinant baculovirus. These proteins were recognized by immune serum from a drug-cured BALB/c mouse. While BALB/c mice immunized with both recombinant antigens and Freund's adjuvants showed $40-100 \%$ survival rate against challenge infection with $B$. rodhaini, saponin failed to induce protection, although significant levels of $B$. rodhaini-specific antibodies were produced in both immunized mice $(1: 1,000-2,000$ by indirect immunofluorescent antibody test). The immunization of IFN- $\gamma$-deficient mice with the recombinant proteins was not protective against $B$. rodhaini infection, indicating that IFN- $\gamma$ is one of the important factors for the survival against lethal B. rodhaini infection.

KEY WORDS: Babesia rodhaini, IFN- $\gamma$, mouse, recombinant antigen, survival.

J. Vet. Med. Sci. 62(7): 717-723, 2000

Babesia rodhaini is an intraerythrocytic protozoan parasite which causes a lethal infection in mice. Acute infection can be cured by chemotherapy in mice, the recovered mice being resistant to reinfection $[16,27]$. Protective immune responses against Babesia infection have been attributed to cell-mediated immunity $[6,9,28]$. In $B$. microti infection, $\mathrm{CD}^{+} \mathrm{T}$ cells and IFN- $\gamma$ play an essential role not only in the resolution of primary infection [9] but also in protective immunity against the challenge infection [8]. Macrophages and T cells are suggested as effector cells for the protective immunity against $B$. rodhaini infection $[17,27]$. Recently, $\mathrm{CD}^{+}$cells have been suggested as major effector cells in the protection against $B$. rodhaini infection [27]. On the other hand, other reports have suggested that $\mathrm{CD}^{+}$cells especially Th1 cells, are responsible for protection against $B$. rodhaini by inducing cell-mediated immunity [14].

Four antigens of $B$. rodhaini have been identified by monoclonal antibodies. These proteins reacted strongly to the immune serum [18]. The DNA sequences of genes encoding these proteins were also analyzed $[18,20]$. Among four antigens, p26 antigen is a merozoite surface protein that has been shown to induce a degree of protective immunity in mice, which is evident both in their increased survival and reduced blood parasitemia [19]. The p26 antigen consists of 337 amino acids, and the molecular masses of precursor and mature proteins are $36.8 \mathrm{~K}$ and $34.5 \mathrm{~K}$, respectively [20]. However, the precise role of this protein for protective immunity against the challenge infection is still unknown. In the present study, recombinant p26 antigens of $B$. rodhaini (Br26) were produced in E. coli and the baculovirus-insect cell system. The effect of the recombinant antigens on the course of infection with $B$. rodhaini in mice was examined.

\section{MATERIALS AND METHODS}

Mice: Female BALB/ c mice were purchased from CLEA (Tokyo, Japan). IFN- $\gamma$-deficient mice were generated as previously described [22]. Male and female IFN- $\gamma$-deficient mice were backcrossed to $\mathrm{BALB} / \mathrm{c}$ for seven generations and maintained by interbreeding with heterozygous animals, and homozygous (-/-) and wild-type littermates (+/+) were identified as described before [22]. All mice were between 5 and 7 weeks old at the time of the experiment. IFN- $\gamma$-deficient mice were housed in filter-topped autoclaved cages and given autoclaved food and water.

Parasite and DNA extraction: Australian strain of $B$. rodhaini was maintained by blood passage as previously described [7]. B. rodhaini-infected erythrocytes (70\% parasitemia) were washed with phosphate buffered saline (PBS), lysed in $0.1 \mathrm{M}$ Tris- $\mathrm{HCl}(\mathrm{pH} 8.0)$ containing $1 \% \mathrm{SDS}, 0.1 \mathrm{M}$ $\mathrm{NaCl}$, and $10 \mathrm{mM}$ EDTA, and then treated with proteinase $\mathrm{K}$ $(100 \mu \mathrm{g} / \mathrm{m} l)$ for $2 \mathrm{hr}$ at $55^{\circ} \mathrm{C}$. The genomic DNA was extracted by phenol-chloroform extraction and precipitated by ethanol. The pellets were resuspended in distilled water and stored at $4^{\circ} \mathrm{C}$ until use.

Expression of recombinant Br26 in E. coli: DNA encoding p26 was amplified by polymerase chain reaction (PCR) from $B$. rodhaini genomic DNA using two oligonucleotide primers with Bam $\mathrm{H} 1$ sites, based on a published sequence for the p26 antigen gene from the Antwerp strain [18]. PCR cycles consisted of an initial denaturation at $94^{\circ} \mathrm{C}$ for $3 \mathrm{~min}$ followed by 30 cycles of $94^{\circ} \mathrm{C}$ for $30 \mathrm{sec}$, annealing at $63^{\circ} \mathrm{C}$ for $2 \mathrm{~min}$, and extension at $72^{\circ} \mathrm{C}$ for $1 \mathrm{~min}$, with a final extension at $72^{\circ} \mathrm{C}$ for $7 \mathrm{~min}$. The amplified DNA was loaded on to $1.5 \%$ agarose gel electrophoresis. For expression in E. coli, a DNA band of the expected size was recovered from the gel 
and ligated into the Bam HI site of the expression vector pGEMEX2. The ligation mix was transformed into competent $E$. coli $\mathrm{DH} 5 \alpha$ cells, and colonies of transformants were selected on LB agar containing $50 \mu \mathrm{g} / \mathrm{m} l$ ampicillin. Plasmid DNA was isolated and checked for the presence of $B$. rodhaini $\mathrm{p} 26$ gene in the correct orientation using appropriate enzyme digests. Plasmid DNA (pGEMEX/Br26) from a selected colony was purified and used to transform $E$. coli JM109 (DE3) for the expression of p26 as a fusion protein of the bacteriophage $\mathrm{T} 7$ gene 10 protein according to the manufacture's instructions (Promega, U.S.A.). Transformed E. coli were grown at $37^{\circ} \mathrm{C}$ in $75 \mathrm{~cm}^{2}$ culture flasks, induced with isopropylthio- $\beta$-D galactoside (IPTG), and then harvested by centrifugation. E. coli were from one culture flask suspended in one $\mathrm{m} l$ of PBS and lysed with lysozyme followed by ultrasonic treatment and used as crude recombinant antigen for immunization of five mice.

Expression of recombinant Br26 using baculovirus: For expression using baculovirus, amplified DNA by the PCR was ligated into the $\mathrm{Bam} \mathrm{H} 1$ site of baculovirus transfer vector $\mathrm{pBacPAK} 8$, and a recombinant transfer vector $\mathrm{pAK} / \mathrm{Br} 26$ was isolated. Purified plasmid DNA was mixed with wild-type baculovirus DNA (Bsu36I-digested linear AcNPV) and transfected into Spodoptera frugiperda (Sf9) cells in TC-100 insect medium (GIBCO BRL, U.S.A.) supplemented with $10 \%$ fetal calf serum and $0.26 \%$ Bacto tryptose broth (Difco, U.S.A.) using the lipofectin reagent (GIBCO RBL, U.S.A.). After 4 days of incubation at $27^{\circ} \mathrm{C}$, the culture supernatant containing recombinant virus was harvested and subjected to plaque purification. The expression of Br26 in plaques was checked by the indirect immunofluorescent antibody test (IFAT) using mouse anti- $B$. rodhaini serum, and a positive plaque was picked. After three cycles of purification, a recombinant baculovirus $(\mathrm{AcBr} 26)$ was obtained. This was then amplified in a $\mathrm{Sf} 9$ cell culture in $75 \mathrm{~cm}^{2}$ culture flasks and harvested by centrifugation. Infected Sf9 cells from one culture flask were suspended in one $\mathrm{m} l$ of PBS and freezedthawed three times and stored at $-80^{\circ} \mathrm{C}$.

Analysis of recombinant antigens: Recombinant antigens in $E$. coli or the baculovirus-insect cell system were analyzed by SDS-polyacrylamide gel electrophoresis (SDS-PAGE) and subjected to immunoblot.

Indirect immunofluorescent antibody test (IFAT): IgG antibody titers were determined by the IFAT using $B$. rodhaini-infected erythrocytes as described previously [26].

Immunization and challenge infection: Recombinant antigen in E. coli or baculovirus-infected Sf9 cell lysates was used for immunization of five mice of each group with $0.01 \%$ saponin or Freund's adjuvant. Five BALB/c or IFN- $\gamma$-deficient mice were immunized two or three times subcutaneously (saponin) or intraperitoneally (Freund's adjuvants) with 0.2 $\mathrm{m} l$ of $E$. coli expressed protein or baculovirus-infected Sf9 cell lysates at 2-week intervals. When Freund's adjuvant was used, the primary immunization was performed with Freund's complete adjuvants and later immunizations were carried out with Freund's incomplete adjuvant.

The Australian strain of Babesia rodhaini was used for the challenge experiments [7]. Mice (four or five mice/group) were challenged with $1 \times 10^{3}$ or $1 \times 10^{4}$ parasitized erythrocytes 2 weeks after the last immunization. Parasitemias in between 200 and $1 \times 10^{4}$ erythrocytes were monitored by microscopic examination of Giemsa-stained thin smears of tail blood prepared every 2 days.

Statistics: Fisher's exact test and Student's $t$ test were used to determine the significant difference in the survival rate and in the parasitemias of mice between the immunized and control groups, respectively.

\section{RESULTS}

Expression of Br26: P26 antigen gene was amplified by PCR from genomic DNA of Australia strain of $B$. rodhaini. The PCR product of P26 antigen gene from Australian strain was smaller than those from Antwerp strain and consisted of 913 base pairs DNA and $80 \%$ homology was observed with p26 of Antwerp strain of $B$. rodhaini. SDS-PAGE analysis of recombinant $\mathrm{Br} 26$ expressed in $E$. coli showed a major band with a molecular weight (MW) of $67 \mathrm{kDa}$ and one with a MW of $36 \mathrm{kDa}$ in the $\mathrm{T} 7$ gene 10 protein used as a control (Fig. 1A). This fusion recombinant protein was recognized by mouse B. rodhaini immune serum (Fig. 1B, lane 1), but the control T7 gene 10 product was not (Fig. 1B, lane 2). Recombinant Br26 expressed in Sf9 cells was not observed as a major band by SDS-PAGE analysis, but immunoblotting analysis detected a major band reacting with the immune serum against $B$. rodhaini in $\mathrm{Sf9}$ cells with a molecular weight of $33 \mathrm{kDa}$ (Fig. 1B, lane 3) as well as the lysate of $B$. rodhaini-infected erythrocytes (Fig. 1B, lane 5).

Antibody responses after immunization with recombinant Br26: Antibody response induced by immunization of five mice with recombinant antigens plus saponin or Freund's adjuvant were determined using serum samples collected before and after the challenge infection. After the second immunization, high specific IgG antibody titers $(1: 1,000$ 2,000 by IFAT) were detected in all five mice immunized with both recombinant antigens regardless of the adjuvants. However, no significant increase of antibody titers were found after third immunization of recombinant antigens. Similar high specific IgG antibody titers were observed one week after challenge infection. In contrast, IgG antibody titers were not detected in the control groups after the second immunization, and very low titers were seen in five mice of the control groups after the challenge infection.

Immunization trials: In a preliminary experiment, the immunizing efficacy of recombinant baculovirus-infected Sf9 cell lysate was assessed with two different adjuvants, saponin and Freund's adjuvants (Fig. 2). When saponin was used for the immunization of mice, five mice immunized three times with both control and Br26 containing cell lysates died with the average peak parasitemia reaching $71.6 \%$ and $73.1 \%$ respectively within 12 days follwing the challenge infection with $1 \times 10^{4}$ parasites. In contrast, when Freund's adjuvant was used, mice immunized three times with cell lysates containing Br26 showed a higher survival rate $(60 \%)$ against 

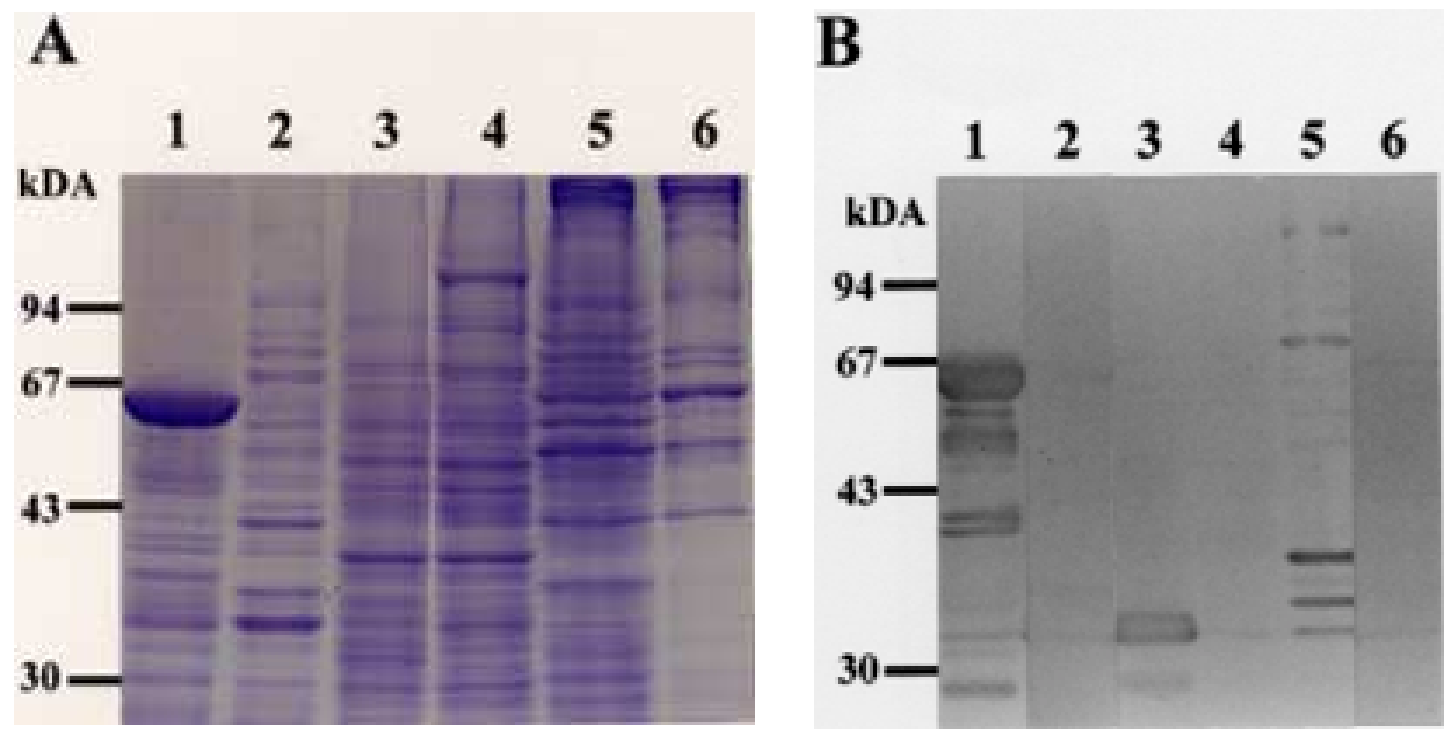

Fig. 1. SDS-PAGE analysis of recombinant Br26 antigen expressed in E. coli and Sf9 cells. (A) Coomassie blue-stained gel. (B) Immunoblot probed with hyperimmune mouse serum against B. rodhaini. Lane 1, Br26 expressed in E. coli; lane 2, T7 gene 10 protein; lane 3, Br26 expressed in Sf9 cells; lane 4, Sf9 cells infected with wild-type baculovirus; lane 5, Babesia rodhaini-infected erytocytes; lane 6, uninfected mouse erythrocytes.

lethal infection with B. rodhaini compared to mice immunized with the same recombinant antigen and saponin. However, there was no statistically significant difference between the group immunized with recombinant antigen plus Freund's adjuvants and the control group inoculated with Freund's adjuvants only, which showed a $40 \%$ survival rate. The parasitemias from both groups immunized with Freund's adjuvants were lower than those from the two groups immunized with saponin. Therefore, Freund's adjuvant was used for further experiments.

Three immunizations of mice with recombinant $\mathrm{Br} 26$ expressed in $E$. coli also resulted in a higher survival rate against B. rodhaini infection in BALB/c mice (Fig. 3). Although one of the four mice immunized three times with pGEMEX/Br26 with Freund's adjuvants died, the three surviving mice showed a $100 \%$ survival rate against challenge infection. Control mice immunized with $\mathrm{T} 7$ gene 10 protein showed a $25 \%$ survival rate against the $B$. rodhaini challenge infection.

Because there was not much difference in antibody responses after the second and third immunizations, five mice were challenged with $1 \times 10^{4}$ B. rodhaini after the second immunization (Fig. 4). Five naive control mice immunized with PBS emulsified with Freund's adjuvants died 10-12 days after the challenge infection with an average peak parasitemia of $83.4 \%$. Mice immunized with recombinant $\mathrm{Br} 26$ expressed in $E$. coli showed a higher survival rate (60\%) compared to the naive control. Mice immunized with recombinant baculovirus-infected Sf9 cell lysates showed a $40 \%$ survival rate, but the difference was not statistically significant compared to naive control. In the mice there was a slow increase in para- sitemia and a significantly lower peak parasitemia compared to that of naive control mice. Mice immunized twice with Freund's adjuvants plus $\mathrm{T} 7$ gene $\mathrm{T} 10$ protein or $\mathrm{Sf} 9$ cells infected with wild type baculovirus showed a $20 \%$ survival rate.

The course of infection of $B$. rodhaini in IFN- $\gamma$-deficient mice: Five IFN- $\gamma$-deficient or BALB/c mice of each group were immunized twice with recombinant $\mathrm{Br} 26$ expressed in $E$. coli or in recombinant baculovirus-infected Sf9 cells emulsified with Freund's adjuvants. In these mice there were no apparent adverse reactions to the immunizations and they were challenged with $1 \times 10^{3} B$. rodhaini. All five IFN- $\gamma$-deficient mice of four experimental groups succumbed on days 8 to 13 , showing higher parasitemia more than $80 \%$ (Fig. 5), whereas $\mathrm{BALB} / \mathrm{c}$ mice showed a lower parasitemia and survival rate in mice immunized with recombinant $\mathrm{Br} 26$ antigen expressed in E. coli or in recombinant baculovirus-infected Sf9 cells, respectively as shown in Fig. 4. These results suggest that IFN- $\gamma$ is one of the important factors for the survival against lethal $B$. rodhaini infection.

\section{DISCUSSION}

In the present study, recombinant antigens of $B$. rodhaini p26 have induced partial survival against lethal challenge infection with $B$. rodhaini when mice were immunized with Freund's adjuvants. The molecular weights of these recombinant antigens expressed in $\mathrm{Sf} 9$ cells transfected with recombinant baculovirus or in $E$. coli were smaller than those of naive antigen. The difference of molecular weight between naive and recombinant antigens may be explained by the difference in parasite strains, the antigenic variation $[2,12]$, or the lack of 


\section{A}
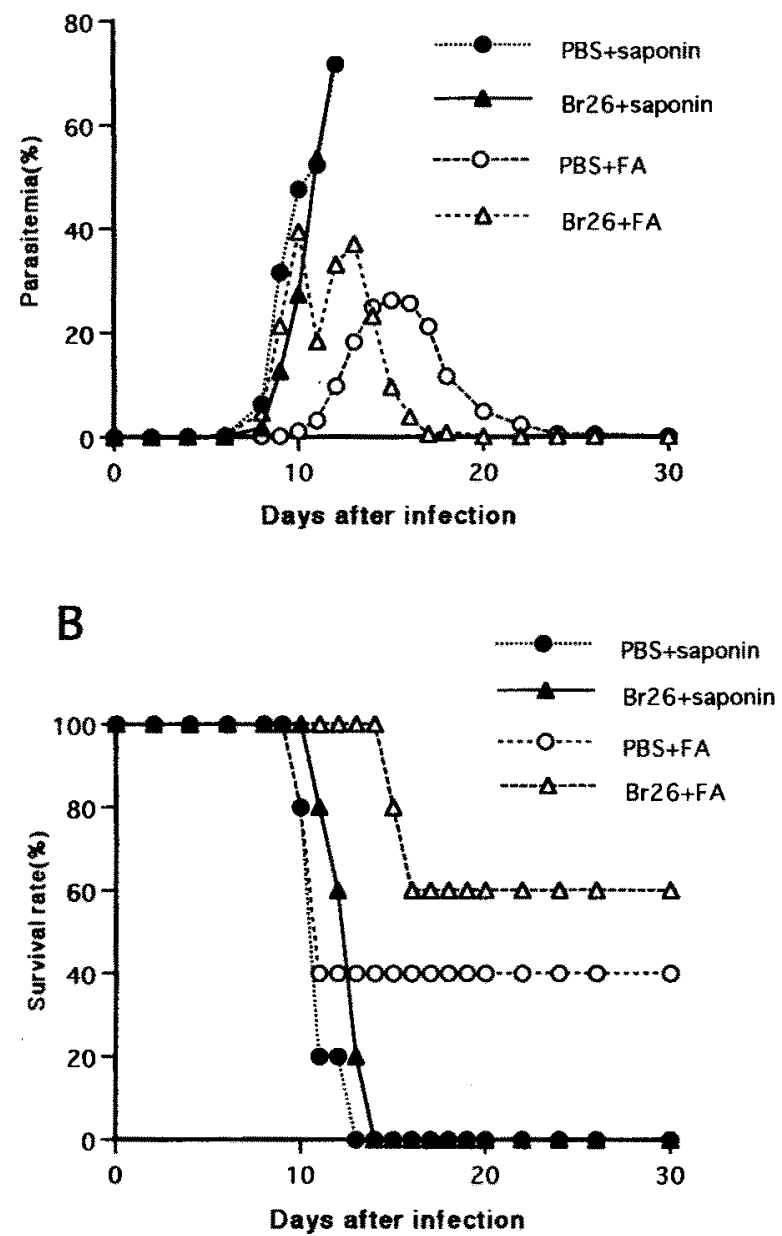

Fig. 2. Comparison of parasitemia and survival rate in mice challenged with Babesia rodhaini after immunizations with recombinant $\mathrm{Br} 26$ antigen expressed in $\mathrm{Sf} 9$ cells transfected with recombinant baculovirus. Five mice were immunized three times with Br26 plus saponin or Freund's complete and incomplete adjuvants (FA) at two-week intervals and were challenged with $1 \times 10^{4}$ B. rodhaini. The graphs show the average parasitemia (A) and the survival rate (B).

glycosilation of recombinant antigen. It should be noted that the gene sequence coding for the p26 was originally obtained from the Antwerp strain [16], whereas the genomic DNA used for PCR in the present study was obtained from the Australian strain. In spite of the smaller molecular weight of recombinant antigens, they were recognized by the immune serum from mice recovered by the chemotherapy. Our results indicate that the recombinant $\mathrm{Br} 26$ protein shares immunologically active epitope with naive p26.

In rodent malaria infection, recombinant antigen was used for the immunization of mice and Freund's adjuvant was more effective than saponin for the induction of protective immunity [3]. In the present study, the combination of recombinant

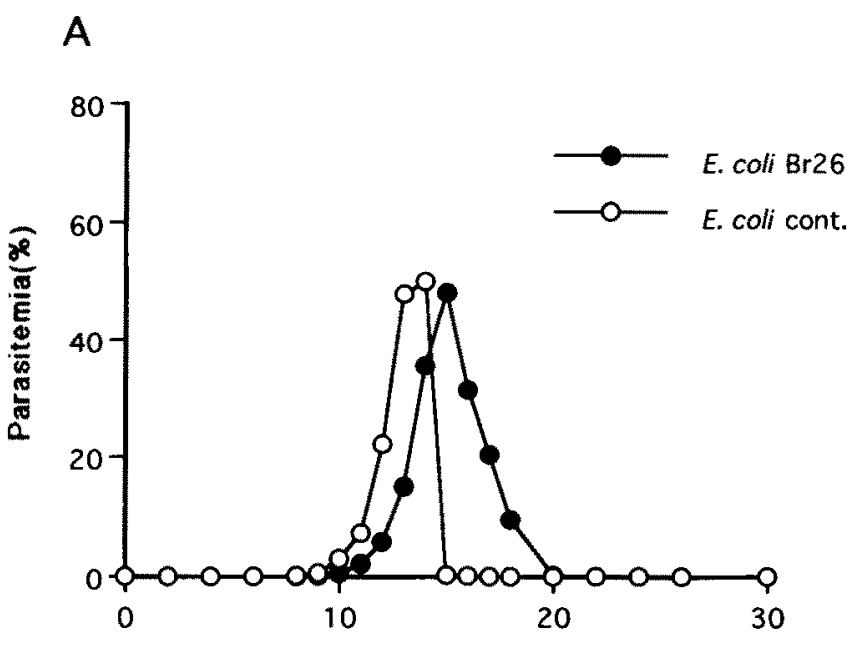

Days after infection

B

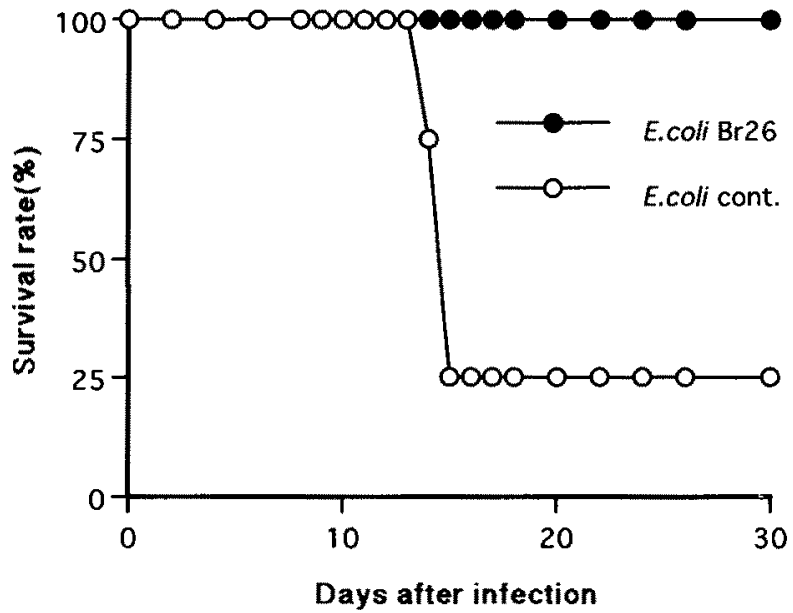

Fig. 3. Comparison of parasitemia and survival rate in mice challenged with Babesia rodhaini after immunizations with recombinant $\mathrm{Br} 26$ antigen expressed in $E$. coli. Four mice were immunized three times with either $\operatorname{Br} 26$ antigen expressed in $E$. coli or T7 gene 10 protein as a control with Freund's complete and incomplete adjuvants (FA). One mouse died after the second immunization. Two weeks after immunization, the mice were challenged with $1 \times 10^{4} \mathrm{~B}$. rodhaini-infected erythrocytes. The graphs show the average parasitemia (A) and the survival rate $(B)$.

antigens and Freund's adjuvants induced a partial survival. Freund's adjuvants are known to induce a strong cell-mediated immunity as well as an antibody response in rodent malaria infection $[3,4]$. Interestingly, immunization of mice with Freund's adjuvants could induce the partial survival against lethal $B$. rodhaini infection and this effect may be explained by the nonspecific activation of macrophages. Fur- 
A

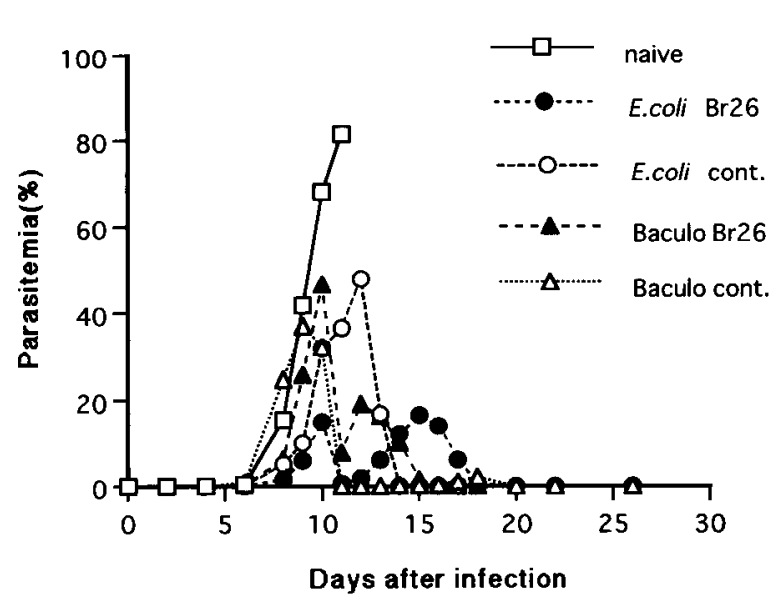

Days after infection



Fig. 4. Comparison of parasitemia and survival rate in mice challenged with Babesia rodhaini after two immunizations with recombinant $\mathrm{Br} 26$ antigens. Five mice were immunized twice with recombinant $\mathrm{Br} 26$ protein expressed in E. coli or in $\mathrm{Sf} 9$ cells transfected with recombinant baculovirus at two-week intervals. The control mice were immunized with $\mathrm{T} 7$ gene 10 protein or Sf9 cells infected with wild-type baculovirus with the same schedule. Mice were challenged with $1 \times 10^{4}$ B. rodhaini infected erythrocytes two weeks after the last immunization. The graphs show the average parasitemia (A) and the survival rate $(\mathrm{B})$.

thermore, nonspecific protective response against lethal infection with $B$. rodhaini may also be explained by the facts that immunization with complete Freund's adjuvants induced Th1 type cytokine responses and immunization with saponin induced Th2-type cytokine responses in Trypanosoma cruzi or ovalbumin antigenic stimulation [21].

In the earlier study [19], immunization with naive, affinity-

\section{A}
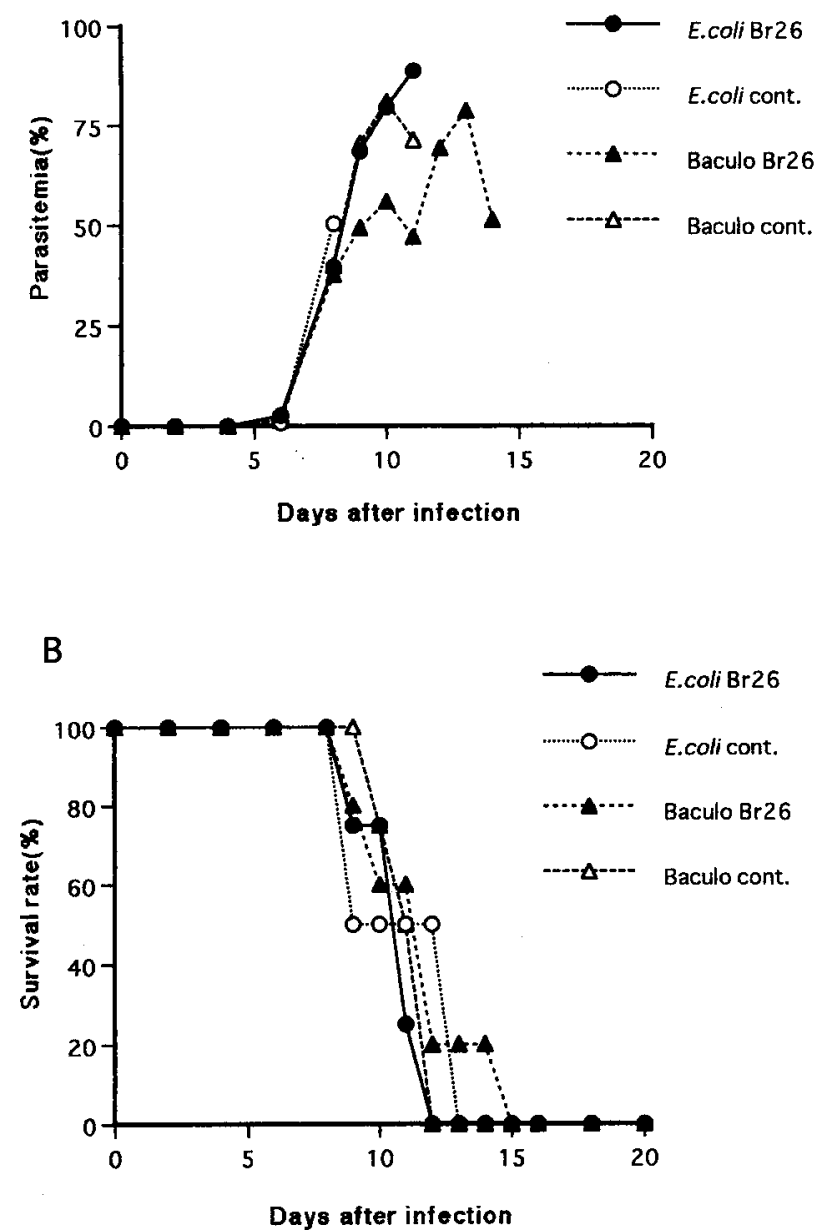

Fig. 5. Effect of immunization with $\mathrm{Br} 26$ antigen in IFN- $\gamma$ deficient mice. Five IFN- $\gamma$-deficient mice were immunized twice with recombinant $\mathrm{Br} 26$ antigens expressed in E. coli and Sf9 cells transfected with recombinant baculovirus. They were then challenged with $1 \times 10^{3} \mathrm{~B}$. rodhaini. The graphs show the average parasitemia (A) and the survival rate (B).

purified p26 antigen induced a degree of protective immunity in mice when saponin was used as an adjuvant. Saponin is a glycoside derived from plants and used as an adjuvant in vaccination against protozoan infections $[10,13,23,24]$. In the present study, however, mice immunized with recombinant antigens in the presence of saponin failed to induce a protective response against lethal challenge infection. The lack of protection in mice immunized with saponin was not due to the failure to respond to intact parasite antigens, since the antibody response to infected erythrocytes in immunized mice with saponin was comparable to that of immunized mice with Freund's adjuvants. Therefore, our results indicate that the antibody response did not correlate the protection against the challenge infection, and cell-mediated immunity rather than humoral immunity is involved in the mechanism behind the 
increased survival of mice immunized with $\mathrm{Br} 26$ recombinant antigen against the challenge infection with $B$. rodhaini.

Failure of IFN- $\gamma$-deficient mice to induce protective immunity against challenge infection provided further evidence that cell-mediated immunity is very important for the protection induced with the recombinant antigens. The importance of IFN- $\gamma$ in the protective immunity has been suggested in Babesia $[5,8,14]$ as well as other intracellular protozoan infections such as Plasmodium, Toxoplasma, and Trypanosoma $[1,11$, $15,25]$. Further studies on IFN- $\gamma$ as well as other cytokine responses such as TNF- $\alpha$, IL-10 and IL-12, and studies on other antigens and adjuvants enhancing specific immune responses will deepen the understanding of the immune mechanism and stimulate the development of vaccines against the Babesia infection.

ACKNOWLEDGMENTS. This work was supported by Grant-in-Aid for Scientific Research (B) from the Ministry of Education, Science, Culture and Sports of Japan.

\section{REFERENCES}

1. Cavacini, L. A., Parke, L. A. and Weidanz, W. P. 1990. Resolution of acute malarial infections by $\mathrm{T}$ cell-dependent nonantibody-mediated mechanisms of immunity. Infect. Immun. 58: 2946-2950.

2. Dalrymple, B. P. 1993. Molecular variation and diversity in candidate vaccine antigens from Babesia. Acta Trop. 53: 227238.

3. Daly, T. M. and Long, C. A. 1996. Influence of adjuvants on protection induced by a recombinant fusion protein against malarial infection. Infect. Immun. 64: 2602-2608.

4. Freeman, R. R. and Holder, A. A. 1983. Characterization of the protective response of $\mathrm{BALB} / \mathrm{c}$ mice immunized with a purified Plasmodium yoelii schizont antigen. Clin. Exp. Immunol. 54: 609-616.

5. Goff, W. L., Johnson, W. C. and Cluff, C.W. 1998. Babesia bovis immunity. In vitro and in vivo evidence for IL-10 regulation of IFN-gamma and iNOS. Ann. New York Acad. Sci. 849: $161-180$.

6. Hanafusa, Y., Onuma, M. and Kamiyama, T. 1998. Partial protection of severe combined immunodeficient mice against infection with Babesia microti by in vitro-generated $\mathrm{CD}^{+} \mathrm{T}$ cell clones. J. Vet. Med. Sci. 60: 401-404.

7. Igarashi, I., Hosomi,T., Kaidoh, T., Omata, Y., Saito, A., Suzuki, N. and Aikawa, M. 1993. Comparison of damage to kidneys and liver caused by lethal Babesia rodhaini infection and non-lethal Babesia microti infection in mice. J. Protozool. Res. 3: 144-155.

8. Igarashi, I., Suzuki, R., Waki, S., Tagawa, Y., Seng, S., Sothyra, T., Omata, Y., Saito, A., Nagasawa, H., Iwakuara, Y., Suzuki, N., Mikami, T. and Toyoda, Y. 1999. Roles of CD4 ${ }^{+}$T cells and IFN- $\gamma$ for protective immunity against Babesia microti infection in mice. Infect. Immun. 67: 4143-4148.

9. Igarashi, I., Waki, S., Ito, M., Omata, Y., Saito, A. and Suzuki, N. 1994. Role of CD4 ${ }^{+}$T cells in the control of primary infection with Babesia microti in mice. J. Protozool. Res. 4: 164171.

10. McColm, A. A., Bomford, R. and Dalton, L. 1982. A comparison of saponin with other adjuvants for the potentiation of protective immunity by a killed Plasmodium yoelii vaccine in the mouse. Parasite Immunol. 4: 337-347.

11. Miller, J. M., Wrightsman, R. A., Stryker, G. A. and Manning, J. E. 1997. Protection of mice against Trypanosoma cruzi by immunization with paraflagellar rod proteins requires $\mathrm{T}$ cell, but not $\mathrm{B}$ cell, function. J. Immunol. 158: 5330-5337.

12. Phillips, R. S., Brannan, L. R., Balmer, P. and Neuville, P. 1997. Antigenic variation during malaria infection: the contribution from the murine parasite Plasmodium chabaudi. Parasite Immunol. 19: 427- 434.

13. Ristic, M. and Montenegro-James, S. Immunization against Babesia. pp. 163-189 In: Babesiosis of domestic animals and man. (Ristic, M. ed.), CRC Press, Boca Raton, Florida.

14. Rosenblatt-Bin, H., Y. Kalechman, A. Vonsover, R. Xu, J. Da, F. Shalit, M. Huberman, A. Klein, G. Strassmann, M. Albeck, B. and Sredni. 1998. The immunomodulator AS101 restores TH1 type of response suppressed by Babesia rodhaini in $\mathrm{BALB} / \mathrm{c}$ mice. Cell. Immunol. 184: 12-25.

15. Ruobing, W., Charoenvit, Y., Corradin, G., de la Vega, P., Franke, E. D. and Hoffman, S. L. 1996. Protection against malaria by Plasmodium yoelii sporozoite surface protein 2 linear peptide induction of $\mathrm{CD}^{+} \mathrm{T}$ cell and IFN- $\gamma$-dependent elimination of infected hepatocytes. J. Immunol. 157: 40614067.

16. Shimada, T., Igarashi, I., Maki, Y., Claveria F. G., Saito, A. and Suzuki, N. 1991. Cellular subsets involved in protective immunity to Babesia rodhaini infection in BALB/c mice. $J$. Protozool. Res. 1: 35-44.

17. Shimada, T., Shikano, S., Hashiguchi, R., Matsuki, N. and Ono, K. 1996. Effects of depletion of T cells subpopulations on the course of infection and anti-parasite delayed type hypersensitivity response in mice infected with Babesia microti and Babesia rodhaini. J. Vet. Med. Sci. 58: 343-347.

18. Snary, D. and Smith, M. A. 1986. An antigenic determinant common to both mouse red blood cells and several membrane proteins of the parasitic protozoa Babesia rodhaini. Mol. Biochem. Parasitol. 20: 101-109.

19. Snary, D. 1987. Structural homology of membrane proteins of Babesia rodhaini. pp. 335-344. NATO ASI Series, Vol. H11, Host-Parasite Cellular and Molecular Interactions in Protozoal Infections.

20. Snary, D. and Smith, M. A. 1988. Sequence homology of surface membrane proteins of Babesia rodhaini. Mol. Biochem. Parasitol. 27: 303-312.

21. Tadokoro, C. E., Macedo, M. S. and Abrahamsohn, I. A. 1996. Saponin adjuvant primes for a dominant interleukin-10 production to ovalbumin and to Trypanosoma cruzi antigen. Immunology 89: 368-374.

22. Tagawa, Y., Sekikawa, K. and Iwakura, Y. 1997. Suppression of concanavalin A-induced hepatitis in IFN- $\gamma-/-$ mice, but not in TNF- $\alpha-/-$ mice: role for IFN- $\gamma$ in activating apoptosis of hepatocytes. J. Immunol. 159: 1418-1428.

23. ten Hagen, T. L., Sulzer, A. J., Kidd, M. R., Lal, A. A. and Hunter, R. L. 1993. Role of adjuvants in the modulation of antibody isotype, specificity, and induction of protection by whole blood-stage Plasmodium yoelii vaccines. J. Immunol. 151: 7077-7085.

24. Timms, P. 1989. Development of babesial vaccines. Trans. $R$. Soc. Trop. Med. Hyg. 83 Suppl: 73-79.

25. van der Heyde, H. C., Pepper, B., Batchelder, J., Cigel, F. and Weidanz, W. P. 1997. The time course of selected malarial infections in cytokine-deficient mice. Exp. Parasitol. 85: 206213. 
26. Waki, S. and Suzuki, M. 1974. Development and decline of antiplasmodial indirect fluorescent antibodies in mice infected with Plasmodium berghei (NK65) and treated with drugs. Bull. WHO 50: 521-526.

27. Zivkovic, D., Seinen, W., Kuil, H., Albers-van Bemmel, C. M. and Speksnijder, J. E. 1984. Immunity to Babesia in mice. I. Adoptive transfer of immunity to Babesia rodhaini with immune spleen cells and the effect of irradiation on the protection of immune mice. Vet. Immunol. Immunopathol. 5: 343357.

28. Zivkovic, D., Speksnijder, J. E., Kuil, H. and Seinen, W. 1985. Immunity to Babesia in mice. III. The effects of corticosteroids and anti-thymocyte serum on mice immune to Babesia rodhaini. Vet. Immunol. Immunopathol. 9: 131-142. 